\title{
The Effect of Entrepreneurship Orientation on Coffee Farming Performance in Banyuwangi Regency (Case Study in Glagah District)
}

\author{
Yusmia Widiastuti ${ }^{1, *}$
}

\author{
${ }^{1}$ Department of Agrotechnology, University of 17 Agustus 1945 Banyuwangi, Banyuwangi, Indonesia \\ *Corresponding author.Email: yusmia@untag-banyuwangi.ac.id
}

\begin{abstract}
Basically everyone has the ability to be an entrepreneur. To be an entrepreneur it takes courage to start something new, therefore there is often fear or doubt in someone in starting to become an entrepreneur because there is no certainty of profit or salary. Many successful entrepreneurs are also started by doubt or fear of failure, but if they are maintained, they will not achieve prosperity. The study was conducted in Glagah District, Banyuwangi Regency with the number of samples used as many as 35 respondents. From the results of the study, it was found that the calculated $t$ value was 2.361 , while the $t$ table was 2.009 . So it can be concluded that the value of $\mathrm{t}$ count $>\mathrm{t}$ table. So it can be concluded that entrepreneurship has a positive effect on the performance of coffee farming. The most influential on performance is the innovative variable of coffee farmers to increase income (value $=0.54$ ). With innovation, the development of utilization to improve product processes, and/or new systems will provide significant or significant value. The determinant coefficient has a value of 0.193 or $19.3 \%$, which means that $19.3 \%$ of the entrepreneurial variable affects the performance of coffee farming, while the remaining $80.7 \%$ is influenced by other variables. From the results of the study, it can be concluded that entrepreneurship has a positive effect on farm performance. As a result, the better the farmer's entrepreneurship, the better his farming performance.
\end{abstract}

\section{Keywords: Entrepreneurship, Performance, Coffee}

\section{INTRODUCTION}

Entrepreneurship has developed quite rapidly in various countries. Entrepreneurship does not only play a role in increasing output and per capita income, but involves the introduction or implementation of changes in the structure of business and society [1]. Advances in technology and science have contributed to encouraging entrepreneurial practices which ultimately lead to various inventions of new products and services for consumers. This certainly opens up new job opportunities, opens up new markets, and in the long term will be able to create business growth in various sectors.

Entrepreneurship is an important concern in the economy of a nation. The progress or decline of a nation is determined by the presence of entrepreneurs. Entrepreneurship is a driving force for the economic growth of a nation. [2] mentions that entrepreneurship and economic growth have a very close and positive relationship where an increase in the number of entrepreneurs causes an increase in a country's economic growth.

So far, the performance of farming is mostly associated with aspects of cultivation techniques. Entrepreneurship has a very important role in improving farm performance. Increased farmer entrepreneurship is shown by an increase in the enthusiasm or desire and perception of farmers to be more successful in running their farming.

Basically everyone has the ability to be an entrepreneur. Everyone also has an opportunity that he can take advantage of to become an entrepreneur by taking advantage of what is available. To be an entrepreneur it takes courage to start something new, therefore there is often fear or doubt in someone in starting to become an entrepreneur because there is no certainty of profit or salary. Many successful entrepreneurs are also started by doubt or fear of failure, but if they are maintained, they will not achieve prosperity. 
With such conditions as mentioned above, it is necessary to increase the productivity of coffee both in quality and quantity. So the purpose of this study is to determine the effect of entrepreneurship on the performance of coffee farming.

\section{THEORETICAL REVIEW}

According to [3] that entrepreneurship can be viewed as a behavior that includes a person's efforts to seize opportunities regardless of how many resources are under the person's control. Then entrepreneurship and entrepreneurship are interpreted with different meanings but in principle have the same purpose and scope. Entrepreneurship is matters concerning a person's courage to carry out business and nonbusiness activities independently.

[4] explained, entrepreneurship is a discipline that will study the values, abilities, and behavior of a person in facing life's challenges and how to obtain opportunities with various risks that they may face. According to [5] entrepreneurship is a dynamic process to create additional wealth. This additional wealth is created by entrepreneurial individuals who take risks, spend time, and provide a variety of products and services.

Performance is an achievement or work result (output) both quality and quantity achieved by human resources per unit time in carrying out their work duties in accordance with the responsibilities given to them. Performance has a close relationship with productivity, because it is an indicator in determining how the effort to achieve a high level of productivity in an organization. In general, productivity implies a comparison between the results achieved (output) and the overall resources used (input). So productivity is how to produce or increase the results of goods and services by utilizing resources efficiently [6].

Performance can be measured using several indicators, including (1) Quality (Quality) is the level at which the process or result of completing an activity is close to perfect. (2) Quantity is the production produced which can also be expressed in units of currency, the number of units, or the number of cycles of activities completed. (3) Timelines are where the activity can be completed, or a production result can be achieved, at the beginning of the specified time in conjunction with coordinating with other product results and maximizing the time available for other activities [7].

\section{RESEARCH METHODOLOGY}

\subsection{Method of Collecting Data}

This research was conducted in Glagah District, Banyuwangi Regency, as one of the producers of Robusta coffee. This study used a descriptive approach with quantitative analysis. Methods of collecting data were survey methods, observations, interviews, and questionnaires supported by secondary data obtained from related agencies.

Data collection through questionnaires was conducted by interview. Each variable is indicated by a statement and each statement in the questionnaire is given a scale using a Likert scale of $1-5$ with the following explanation:

$1=$ strongly disagree with the statement in the questionnaire and have never carried out the activities in the statement on the questionnaire

2 = disagree with the statement in the questionnaire and rarely do the activities in the statement on the questionnaire

$3=$ neutral with the statements in the questionnaire and sometimes carry out the activities in the statements in the questionnaire

$4=$ agree with the statement in the questionnaire and often carry out the activities in the statement on the questionnaire

$5=$ strongly agree with the statement in the questionnaire and always carry out the activities in the statement on the questionnaire

Entrepreneurship indicators are; Innovative, willing to take risks, and independent. Innovativeness is the ability to create a new idea in farming. Dare to take risks is to dare to take risks with the calculations taken, Independence is not taking decisions from others

The performance indicators are; marketing and revenue. Marketing increases from being able to acquire new markets or being able to expand marketing channels. Revenue is measured when increased compared to the previous period.

\subsection{Population and Sample}

The population here are coffee farmers and traders in Banyuwangi Regency. Due to the large number of samples, samples were taken. 
The sample is part of the number and characteristics possessed by the population [8] According [9] if the population is large or more than 100 , then $10-15 \%$ or $20-25 \%$ or more can be taken. To determine how many minimum samples needed can be done by using the formula method. The number of samples used as many as 35 respondents

This study uses a purposive sampling technique, which is a sampling technique based on the researcher's considerations regarding which samples are the most appropriate, useful and considered to be representative of a population (representative). Data analysis using Multiple Linear Regression Analysis with the help of SPSS version 23 .

\section{RESULTS AND DISCUSSION}

\subsection{Overview of the Characteristics of Coffee Farmers}

Coffee farmers who become respondents are in the productive age range, ie $61 \%$ of the respondents are in the age range of $35-55$ years, and $25 \%$ of respondents are in the age range of 25-35 years. While $8 \%$ are over 55 years old and $6 \%$ are under 25 years old.

Because most of the respondents are middle-aged, this indicates that their work as coffee farmers is a job that is the main alternative compared to other jobs.

As many as $62 \%$ of respondents have an education level equivalent to high school. This means they are better able to absorb the latest technology related to coffee farming management and analyze various situations and think insights. According to [10], an entrepreneur with adequate educational and knowledge capital can more easily adapt to his environment. $42 \%$ of coffee farmers who are respondents have experience in farming for a period of 5 - 10 years. The ability of human resources (HR) of coffee farmers is generally based on working experience (learning by doing) in the family and neighbors who cultivate coffee. Because most coffee farming has a large area of land and is a hereditary business. The area of coffee farming land owned by respondent farmers ranges from 0.5 to 1 hectare $(43 \%)$, then less than 0.5 hectares $(37 \%)$.

\section{2. $F_{\text {test }}$ Result}

To find out whether the independent variables simultaneously have an influence on the dependent variable or have no effect, the $F_{\text {test }}$ is used, by comparing $\mathrm{F}_{\text {count }}$ and $\mathrm{F}_{\text {table }}$ at a $5 \%$ significance level.
If $\mathrm{F}_{\text {count }}>\mathrm{F}_{\text {table }}$ or $\mathrm{Sig} \mathrm{F}_{\text {value }}<0.05$ means $\mathrm{Ho}$ is rejected, otherwise $F_{\text {count }}<F_{\text {table }}$ or Sig $F_{\text {value }}>0.05$ means Ho is accepted. Based on the results of the analysis, the results of the $F_{\text {test }}$ can be presented in Table 1 .

Table 1. Multiple Regression Analysis Results

\begin{tabular}{|c|c|c|}
\hline $\begin{array}{l}\text { Alternative } \\
\text { Hypothesis }\end{array}$ & $\mathrm{F}_{\text {table }}$ & Information \\
\hline $\begin{array}{l}\text { There is a } \\
\text { simultaneous } \\
\text { significant } \\
\text { effect of the } \\
\text { entrepreneurial } \\
\text { variable (X) on } \\
\text { the performance } \\
\text { of coffee } \\
\text { farmers }(Y)\end{array}$ & $\begin{array}{l}\mathrm{F}_{\text {count }} \\
51,235 \\
\mathrm{~F}_{\text {table }} \\
4,13 \\
\text { Sig. F value }= \\
0,000\end{array}$ & $\begin{array}{l}\text { Ho rejected / } \\
\text { Ha accpeted }\end{array}$ \\
\hline
\end{tabular}

Source: Primary data processed, 2021

From the results of multiple regression analysis using df $1=1$ and df $2=34$ at an alpha of 5\% obtained $\mathrm{F}_{\text {table }}$ of 4.13. While $\mathrm{F}_{\text {count }}$ is obtained at 51.235 so that from the above calculation it can be seen that $\mathrm{F}_{\text {count }}>\mathrm{F}_{\text {table, }}$, so $\mathrm{Ho}$ is rejected and $\mathrm{Ha}$ is accepted, thus it can be said that simultaneously There is a simultaneous significant effect of the entrepreneurial variable $(\mathrm{X})$ on the performance of coffee farmers $(\mathrm{Y})$.

\subsection{2 $T_{\text {test }}$ Result}

To determine the effect of the independent variable, namely the entrepreneurial variable, the t-test (t-test) is used, namely by comparing the $t_{\text {count }}$ value with $t_{\text {table, while the }} t_{\text {table }}$ value at $5 \%$ alpha can be obtained a number of 2,009. If $t_{\text {count }}>t_{\text {table }}$ or Sig.t value $<0.05$ means Ho is rejected, otherwise $t_{\text {count }}<t$ table or Sig.t $t_{\text {value }}>0.05$ means Ho is accepted. Below are presented the results of the comparison between the values of $t_{\text {count }}$ and $t_{\text {table. }}$.

Tabel 2. $\mathrm{T}$ test results

\begin{tabular}{|c|l|c|}
\hline \multicolumn{1}{|c|}{ Variable } & \multicolumn{1}{|c|}{ Score } & Information \\
\hline Entrepreneurship & $\mathrm{t}$ value $=$ & Significant \\
& 2,361 \\
& Sig. $\mathrm{t} \quad=$ & \\
& 0,000 \\
$\mathrm{t}$ table $=2,009$ & \\
\hline
\end{tabular}

Source: Primary data processed, 2021

Table 2 shows that the entrepreneurship variable with a significant value of 0.000 is smaller than the significant value of 0.05 . Then the $t_{\text {count }}$ value is 2.361 
which is smaller than the ttable which is 2.009. So it can be concluded that $\mathrm{Ho}$ is rejected and $\mathrm{Ha}$ is accepted, which means that partially the entrepreneurial variable has a significant effect on the performance of coffee farmers.

Based on Table 3, we can see that all variables have a loading factor value of more than 0.5 . This means that 1 is considered to have a strong enough validation to explain the latent construct [11].

Table 3. Small Scale Loading Factor $(\lambda)$ Value

\begin{tabular}{|l|l|c|l|}
\hline $\begin{array}{l}\text { Latent } \\
\text { Variable }\end{array}$ & $\begin{array}{l}\text { Manifest } \\
\text { Variables }\end{array}$ & $\boldsymbol{\Lambda}$ & Information \\
\hline \multirow{4}{*}{ Entrepreneurship } & Innovative & 0.885 & Valid \\
\cline { 2 - 4 } & $\begin{array}{l}\text { Willing to } \\
\text { Take Risks }\end{array}$ & 0.532 & Valid \\
\cline { 2 - 4 } & Independent & 0.824 & Valid \\
\hline \multirow{2}{*}{$\begin{array}{l}\text { Coffee farming } \\
\text { performance }\end{array}$} & Marketing & 0.836 & Valid \\
\cline { 2 - 4 } & Revenue & 0.892 & Valid \\
\hline
\end{tabular}

Source: Primary data processed, 2021

After the innovation that significantly affects the performance of coffee farmers is independence $(\lambda=$ $0.824)$. Independence in business is needed so that these business actors can compete with other business actors competitively [12] Entrepreneurial independence refers to attitudes and business conditions with an entrepreneurial spirit to be able to meet needs and rely on their own abilities [13] Independence provides an opportunity for entrepreneurs to be able to determine their own goals and make the right decisions for their business. Therefore, this independence is important to be cultivated in entrepreneurs so that the businesses they establish can compete competitively and provide the expected results.

The last point of entrepreneurship is the courage to take risks $(\lambda=0.532)$. Taking risks is one of the keys to starting a business. That's because the components are followed by many things such as daring to experience losses, daring to make decisions, and daring to face problems. However, this variable is one of the fairness in entrepreneurship. By daring to take risks, a coffee farmer will dare to try new things.

From the coffee farmer's perspective, income $(\lambda=$ 0.892 ) has the biggest influence. This means that yield orientation is still the main focus of coffee farmers in doing their farming. It is impossible for a farmer to carry out his farming to be oriented towards experiencing losses. Of course everyone wants to get the best results.
In addition to income, the performance of coffee farmers which is quite influential is marketing $(\lambda=$ 0.836). As stated by [14], entrepreneurial marketing is an organizational function and a set of processes for creating, communicating and delivering value to customers and for managing customer relationships in a way that benefits the organization and its stakeholders, and which is characterized by innovation, proactive risk taking, and possibly the resource is currently controlled.

From the results of the study, it was found that the calculated $t$ value was 2.361, while the table was 2.009. So it can be concluded that the value of tcount > ttable. So it can be concluded that entrepreneurship has a positive effect on the performance of coffee farming. The most influential on performance is the innovative variable of coffee farmers to increase income (value $=0.54$ ). With innovation, the development of utilization to improve product processes, and/or new systems will provide significant or significant value. In addition, coffee farmers can play a greater role in facing challenges. Innovation itself can be interpreted as an effort or activity to develop or maximize existing resources.

There is something different about innovation that is not found elsewhere. And this will attract consumers to try the product. So that directly or indirectly will increase the income of coffee farmers. From the correlation value, it is found that the correlation between entrepreneurship and performance is 0.536 , which means the relationship between the two variables is strong.

The determinant coefficient has a value of 0.193 or $19.3 \%$, which means that $19.3 \%$ of the entrepreneurial variable affects the performance of coffee farming, while the remaining $80.7 \%$ is influenced by other variables.

Entrepreneurs with competencies include being able to control risk well, always looking for and analyzing information on new business opportunities, proficient in communicating, dynamically proven to be able to encourage business performance [15]. In addition, business performance can be improved by building a wider social network, having leadership in running the business, being able to negotiate and being responsible and always able to solve problems [15].

This research proves that entrepreneurial competence is very important to be owned by entrepreneurs because it is a valuable resource, rare (unique), cannot be imitated (cannot be easily sold or 
traded), and non-substitutable. This is an advantage and creates performance.

\section{CONCLUSION}

From the results of the study, it can be concluded that entrepreneurship has a positive effect on farm performance. As a result, the better the farmer's entrepreneurship, the better his farming performance.

This study aims to examine in depth the relationship and influence of entrepreneurship on performance in Banyuwangi Regency (a case study in Glagah District). This study proposes a hypothesis to answer the research problem. The results of hypothesis testing provide the conclusion that entrepreneurial competence improves business performance. In other words, the higher the entrepreneurial competence, the higher the business performance

Based on the research results, the practical implications that can be obtained from the results of this study are entrepreneurial skills that must be owned and improved by an entrepreneur because it is proven to be able to encourage business success. risk. , search and analyze information, communication skills, dynamic, and build social networks.

\subsection{Contributions}

From this research it is known that entrepreneurial orientation affects the performance of coffee farming. This will be more profitable for people who are engaged in the coffee sector, from upstream to downstream because with an entrepreneurial orientation they will be more able to innovate, dare to take risks, and independent.

So that Banyuwangi which has many people's coffee plantations and its people who are engaged in the coffee sector will be able to move massively and confidently because the entrepreneurial spirit does affect the performance of coffee farming. The end result that is expected is that the welfare of coffee farmers will increase, businesses in the coffee sector, both in the form of raw coffee and processed coffee, can move and support the regional economy.

\section{ACKNOWLEDGMENTS}

The author would like to thank the coffee farmers and traders in Glagah District, Banyuwangi Regency. And also to the Chancellor, Dean of the Faculty of Economics, University of 17 August 1945 Banyuwangi, colleagues who have provided input and suggestions for the perfection of this research, and all parties who have helped the realization of this research, hopefully this research can be useful for science

\section{REFERENCES}

[1] F. Slamet, et al ., Dasar-dasar Kewirausahaan: Teori dan Praktik. Jakarta: PT Indeks, 2014.

[2] M. Casson, B. Yeung, A. Basu, and N. Wadeson, The Oxford Handbook of Enterprneurship. New York (US): Oxford University Press, 2006.

[3] MT Rionga and Y. Firdaus, Tenaga kerja. Bandung: Alfabeta, 2007.

[4] Suryana, Kewirausahaan. Jakarta: Salemba Empat, 2014.

[5] B. Alma, Kewirausahaan. Bandung; Alfabeta, 2017.

[6] A. N. Rumengan, et al., "Analisis Citra Merek, Kualitas Produk, dan Strategi Harga terhadap Keputusan Pembelian Mobil Daihatsu Ayla Cabang Manado." Jurnal EMBA : Jurnal Riset Ekonomi, Manajemen, Bisnis Dan Akuntansi, vol. 3, no. 2, 2015, doi: https://doi.org/10.35794/emba.3.2.2015.8696.

[7] Rosmaini, and H. Tanjung. "Pengaruh Kompetensi, Motivasi Dan Kepuasan Kerja Terhadap Kinerja Pegawai." Jurnal Ilmiah Magister Manajemen, vol. 2, no. 1, pp. 1-15, 2019, doi: https://doi.org/10.30596/maneggio.v2i1.3366.

[8] Sugiyono, Metode Penelitian Pendidikan Pendekatan Kuantitatif, kualitatif, dan $R \& D$. Bandung: Alfabeta, 2010.

[9] S. Arikunto, Prosedur Penelitian: Suatu Pendekatan Praktik. Jakarta: Rineka Cipta, 2013.

[10] F. Welter, D. Smallbone, N. Isakova, and E. Aculai, The role of gender for entrepreneurship in a transition contex. UK: Elgar, 2007.

[11] I. Ghozali, Desain Penelitian Eksperimental. Semarang: Universitas Diponegoro, 2008.

[12] E. Purwanti. "Pengaruh Karakteristik Wirausaha, Modal Usaha, Strategi Pemasaran Terhadap Perkembangan Umkm Di Desa Dayaan Dan Kalilondo Salatiga." Among Makarti, vol. 5, no. 1, 2012, doi: https://doi.org/10.52353/ama.v5i1.65. 
[13] Sukirman. Jiwa Kewirausahaan dan Nilai Kewirausahaan, Hubungan Jiwa Kewiausahaan dengan perilaku Kewirausahaan, Vol 20, 2017.

[14] J. D. Krauss, Antennas : For All Applications, 3rd edition. New York: McGraw-Hill Book Company, 1998.

[15] Robles, Lorena, and M. Z. Rodríguez. "Key Competencies for Entrepreneurship." Procedia Economics and Finance, vol. 23, 2015, pp. 828-32, https://doi.org/10.1016/s22125671(15)00389 